\title{
S-Commerce Buying Decision Model for Second-Hand Products in Thailand: A Conceptual Framework
}

\author{
Tharinee Auttaput ${ }^{1}$, Wornchanok Chiyasoonthorn ${ }^{1+}$ and Singha Chaveesuk ${ }^{1}$ \\ ${ }^{1}$ Faculty of Administration and Management, King Mongkut's Institute of Technology Ladkrabang, \\ Bangkok, Thailand
}

\begin{abstract}
In Thailand, social commerce (s-commerce) is a new development in e-commerce that uses social media to empower customers to interact with sellers and other buyers on the Internet. The advancement of Web technology and social media platform gives rise to s-commerce which can act like a mechanism for businesses and customers to interact. S-commerce reestablished the social aspect of shopping in e-commerce. It especially increases the amount of social behavior in the online environment. In addition, the nature of the second-hand economy has changed significantly with the beginning of online technology, services, and platforms, i.e., the way second-hand product trade is implanted has changed by s-commerce. Inevitably, the related issues of social network marketing and trust between buyers and sellers have been also been a focus of attention for researchers in order to expand the current understanding of this phenomenon, especially regarding technological marketing and users' trust. Accordingly, the main objective of this study was to systematically review and develop a conceptual framework of s-commerce buying decision model for second-hand product trade in Thailand. This study theorizes the nature of social aspect of online s-commerce behavior. Researchers employ a set of digital marketing mix and a trust model for consumers' Internet shopping that could explain current online purchase behavior. Finally, this proposed model provides potential factors that affect the buying-decision behaviors of second-hand products through s-commerce in Thailand.
\end{abstract}

Keywords: S-commerce, trust; digital marketing mix, second-hand products, second-hand economy, buying behaviour.

\section{Introduction}

The increased internet usage has catalysed the changes to new business models such as electronic commerce (e-commerce), mobile commerce (m-commerce), and click and mortar [1]. E-commerce has become a popular alternative to customers since it is more convenient than conventional offline shopping. According to an Electronic Transactions Development Agency (Public Organization) ETDA survey, the value of e-commerce in Thailand has increased over 14\% during 2016 and 2017 and is expected to rise 10\% more by 2018 , creating a net sale of three billion baht [2]. A recent study shows that more than $70 \%$ of consumers rely on users' comment on social networks in their decision to purchase a product [3]. More than $40 \%$ of social media users have purchased a product after it was put on social networking sites (SSNs) such as Facebook or Twitter [4]. The main development of social media and SSNs is to become a new commercemodel, a social commerce (S-commerce) [5] enabling users to conduct selling, buying, comparing, and sharing of information about products and services in e-marketplaces and online communities [6]. Scommerce enables online users to share information and reshapes their information-seeking and sharing behaviour [7]. As s-commerce encourages more one-to-one interactions [8], new design features based on social media and advanced Web capabilities that include list of recommendation, customer rating, comment, social proof, and reciprocity application help enhance customer participation and allow them to acquire

\footnotetext{
+ Corresponding author. Tel.: + 662-329-8460; fax: +662-329-8461
}

E-mail address: wornchanok.ch@kmitl.ac.th. 
sufficient information for making a purchase decision. As a results, they create a more trustworthy and sociable online transaction environment [8], [9].

Several retailing sectors have used s-commerce to enhance their businesses, including grocery items, electronics, and performance/event tickets, and offered generous discount on the products and services. Second-hand product market is one of the business sectors that use s-commerce as a channel to reach their customers. This market has been growing rapidly in Thailand and represents a significant proportion of the global market as second-hand economy. A 2017 'second-hand buying' report has identified that most Australians (86\%) prefer buying second-hand products over brand new ones which is motivated by the desire for paying less [10]. Moreover, another Canadian 'second-hand buying' report by the Kijiji Second-Hand Economy Index 2017 shows that a total of 1.9 billion goods was granted a second life with a value of \$29 billion sales on all second-hand transactions [11]. This implies the considerable potential of second-hand markets in increasing customer demand. Second-hand market has extended from traditional markets to online environment.

This newly interactive online commerce [12] results in a great number of sales in online environment, indicating a significant change of decision-making behavior in making a purchase compared to that of the conventional buying model. Based on several marketing reviews, businesses are integrating social media into their e-commerce to meet specific customer needs [13], [14]. Online second-hand retailers need to understand these new forms of customers' buying behavior in terms of marketing framework, the types and amounts of products bought, the frequency of purchasing, and the digital channel selected [15]. Customers might be concerned about the remaining life of the product whether it could perform its intended function consistently for a satisfactory long period of time. Thus, consumers are no longer recipients of traditional marketing mix models, but in s-commerce, they positively engage with sellers and other buyers in information sharing. Buyers learn from other buyers' experiences [16]. Moreover, some sellers failed to implement s-commerce properly, so there have been many complaints about trust, security, and privacy in information exchange [17], [18]. Previous research regarding various forms of e-commerce indicate that lack of trust is one of the most compelling reasons that make consumers hesitate to make an online purchase [18], [19]. Particularly, trust-building is more important for s-commerce than other forms of commerce because scommerce is built on SNNs, where users create content and share it with other users on their own. Although these positive influences have been widely recognized, the new paradigm of the marketing mix and trust model which s-commerce applies has not been completely understood, nor their impacts on buying decision.

As online resale of used goods is growing, it has been noticed that few researches have been conducted and only on a small fraction of the second-hand market [20]. Previous researches show that online secondhand buying behavior is limited [12][21]. The phenomenon of s-commerce for second-hand products has not been investigated much in the past in terms of consumers' buying decision behaviour. Therefore, the purpose of this study was to develop a conceptual framework of s-commerce buying decision model for second-hand products in Thailand in order to explain initial factors that might have positive impacts on consumers' buying behavior indicating purchasing frequency and the number of repurchasing. This operationalization could indicate customer loyalty generation and profits for sellers as well as their gaining of competitive advantages. This framework is based on a marketing mix model for digital products and a trust model for consumer Internet shopping in the domain of information technology management.

\section{Literature Reviews}

\subsection{Social Commerce (S-Commerce)}

S-commerce as the evolution of e-commerce [8] refers to the delivery of e-commerce activities and transactions through the social media context [17]. S-commerce is consisting of three main attributes: social technologies (e.g. Web 2.0); community interactions, and business activities. This form of Internet-based and online social media makes people participate actively in the marketing and selling on products and services in online marketplaces and communities [22]. These social media practice and Web 2.0 technologies involve many commercial activities that can assist in consumers' pre-buying product evaluation, shopping decisions, and post-buying behavior. S-commerce usage could be a good strategy for increasing sales by retaining and 
developing both current and new customers [23]. S-commerce is used for firms to present online business online and achieve marketing values [22]. Moreover, consumers tend to be influenced by connecting their social interactions when they are making purchase decisions [24].

\subsection{Digital Marketing Mix}

Consumer behaviour is changing as a result of access to a variety of online contexts. Digital technologies are changing the environment in terms of reducing information asymmetries between seller and customers. Regarding this, digital marketing is a theme of interests to marketers [24]. Digital marketing describes in terms of the marketing of products and service using digital channels with digital technologies to acquire customers and build their preferences, promotes products or services, retain customers, and increase sales. Previous research suggests that more than $90 \%$ of online consumers read reviews before making buying products and more than $60 \%$ of all buyers of consumer products are based on user-generated-content [25] [26]. Digital technologies are used to facilitate customer to customer interactions through online media such as word-of-mouth, online reviews, and ratings.

In the era of e-commerce, [27] noted that consumer-oriented marketing requires the consideration of the 4Cs marketing mix based on 4Ps traditional marketing mix (product, price, place, promotion) used as the development of marketing mix adapted to the needs of e-commerce [28]. 4 C's marketing mix is used as a variety of all the factors which managers may leverage to satisfy market needs. Previous research indicated that the 4Cs model is appropriate to study digital products in terms of digital marketing [28][29]. The context of this framework concludes four constructs (customer value, cost, convenience, and communication): 1) concentrating on what customers want or need; 2) decreasing the cost of fulfilling the customer's demand; 3 ) purchasing as convenient as possible; and 4) conveying communication with customers as importance. Thus, new digital marketing mix constructs are described. First, customer solution is considered as augmenting the core product with digital service, networking of products using digital technologies to release the dormant value inherent in the products, and morphing products into digital services. Next, customer cost is indicated that the reduction in menu costs associated with digital technologies also leads to opportunities for dynamic pricing and yield management in product and service platforms traditionally sold with list prices. Then, convenience is showed that the rise of new channels form customers and promotions, not only online and mobile, but also social channels, search engines, and e-mail helping firms to provide significant value to customers and also acquire the right customers and increase customer value. Last, communication means that the digital environment provides the way to reach customers and promote products and services via e-mails, display advisements, and social media in order to build brands and affect outcome variables of interest [30][31][32].

\subsection{Trust Model for Consumer Internet Shopping}

Based on the summary of the different aspects of trust, [33] defined trust as a subjective assessment of the reliability and accuracy of information received or transferred in a business situation. Trust is the main aspect in economic transactions [34], particularly for e-commerce [35] and s-commerce [36]. It showed that this is the most important for the success of e-commerce business [37]. Successful e-commerce platforms are those which could invoke consumers' trust and lower customers' risk perception through marketing activities and reliable technologies. [38] suggested that users are more likely to trust e-commerce sites than scommerce ones over privacy and security. Thus, a trust model for consumer Internet shopping [39] will be used to identify trustworthiness attributes

First, trustworthiness of Internet merchant is conceptualized trust as a set of specific beliefs including integrity, benevolence, and ability leading to s-commerce trade from buyer perspective [39]. These three constructs indicates the concept of seller reputation. Trust in the online seller is considered as a major construct in this study. Second, trustworthiness of Internet shopping medium is defined as the extent to which consumers trust the computerized medium in terms of interactions with s-commerce [39][40]. This construct explains the perceived technical competence, the perceived performance level, and users' understanding of specific characteristics and processes governing the behavior of s-commerce. While SNSs usefulness promotes decision for buying trust mechanisms help users cope with risks [41]. These three factors encompass and represent the concept of reliability and usefulness. Last, contextual factors refer to 
noteworthy issues of security and privacy in s-commerce [39][42]. Previous research suggested that safety in the transaction is a major factor reducing online purchases and indicated that privacy and security is an important factor influencing trust [43]. Users believe that s-commerce provides a high level of security in terms of transactions and related information [44].

\subsection{Online Buying Behavior}

In the business model of e-commerce or s-commerce, the importance of trust in consumer purchasing decisions is significant interest to retailers [45] because it is considered to be the most important factor influencing buying behavior [46]. Moreover, marketing can positively influence consumer beliefs about performance on products or services [47] and might reduce the chance of buying [48]. Furthermore, online consumers try to acquire as much information as before buying, while they also engage in customer-tocustomer communication, particularly with respect to price and quality [49]. As the complexity of consumers' buying behaviour, they try to buy products and services as convenience considering on how appropriate of perceived customer cost, security, and performance [50].

\section{Conceptual Framework and Hypothesis Development}

The purpose of this study is to build a conceptual framework of s-commerce buying decision for secondhand products by using and applying the trust model for consumer Internet shopping and digital marketing mix framework as shown in Figure 1. Based on the trust model, the factors of reputation, reliability, usefulness, privacy, and security will be applicable to find the behavior of buying decision.

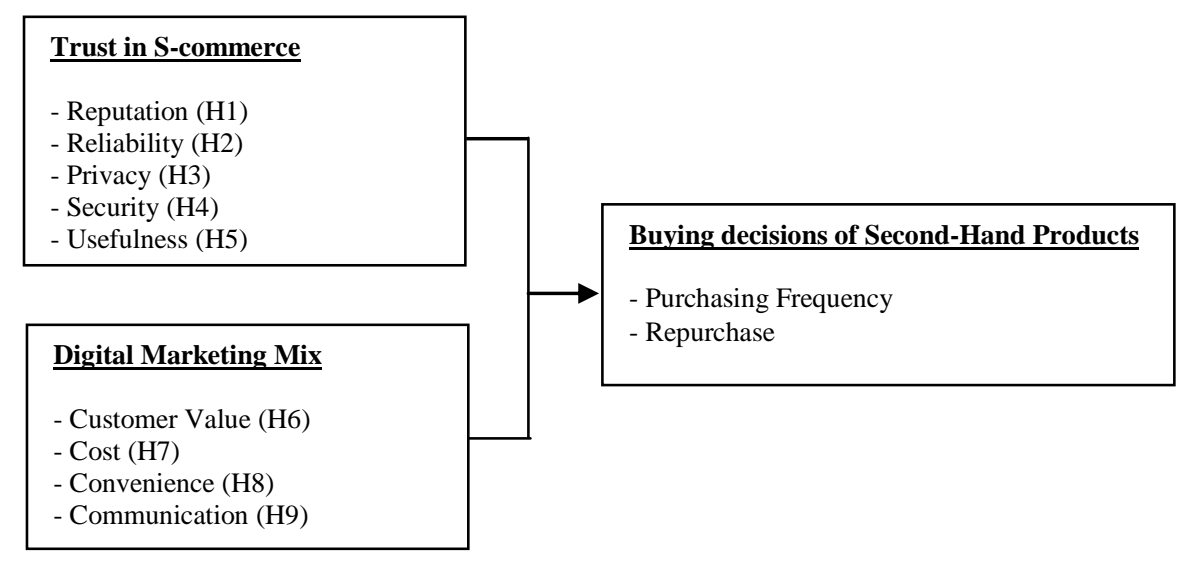

Fig. 1: A conceptual framework.

Reputation is defined as the extent to which buyers believe seller sites are competent or honest and benevolent. Previous research claimed that consumers' perception of the reputation of e-commerce plays a crucial role relating their trust [51][52]. Also, based on marketing behavior review, reputation is shown to have a positive impact on the buyers' trust in the seller site [69]. S-commerce users are likely to consider Reputation as a vital factor when buying products or services. Next, reliability is defined as the ability of online retailers to provide the service to meet customer expectation and also fulfill customers' order precisely [54]. Security refers to a consumer's perception that the Internet merchant will fulfill security requirements (e.g. authentication, integrity, and encryption) indicating as security features (e.g. a security policy, a security disclaimer, and a safe shopping guarantee). Previous research suggests that insufficient trust in the security and reliability of business transactions over the Internet is a common concern of online consumers [55]. Scommerce users are likely to consider Reliability and Security as important factors when making a decision on buying products or services. Then, privacy is defined as privacy protection behaviors involving behavioural efforts to present privacy loss [56]. Privacy protection refers to a consumer's perception of the likelihood that the Internet merchant tries to protect consumer's confidential information acquired during electronic transactions from unauthorized use. Prior research indicated that online buyers do not trust firms to keep their information private even if the firms promise to do so [57]. S-commerce users are likely to 
consider Privacy as an important factor when making a decision on buying products or services. Last, usefulness is described as users tend to use an application to the extent they believe it will help them perform [58]. If online users feel that e-commerce is useful, they will likely perceive it to be competent and capable. Then, competency is one of the elements of trust [58][59]. Prior research indicated that usefulness is shown to be a strong factor online trust [61]. S-commerce users are likely to consider Usefulness as an important factor when making a decision on buying products or services. Therefore, this study presents hypotheses as follows:

H1: Reputation will have a positive effect on buying decisions for second-hand products

H2: Reliability will have a positive effect on buying decisions for second-hand products

H3: Privacy will have a positive effect on buying decisions for second-hand products

H4: Security will have a positive effect on buying decisions for second-hand products

H5: Usefulness will have a positive effect on buying decisions for second-hand products

The Digital marketing mix is added to the trust model to explain buying behaviour of s-commerce. There are four factors in this framework. First, a customer wants and needs (products) are defined as anything that can be offered to a market to satisfy a want or need as an oriented model based on customer need [62]. These attributes are as the consumer-centric environment, creating digital value, low search costs, 24/7 trade, information content and accessibility, product reviews, and information support [63]. Customer value is essential to focus on how digital technologies augmenting and transforming the core products. This is an effort in providing new values to consumers. Thus, it is very important to build customer values strategy based on customer needs and the particularly desired product. Next, cost to the customer is considered as the cost customers willing to pay. These attributes are cost reduction, negotiation, segmented pricing, zero-based pricing [63]. Consumers can understand product prices that consumers are able to take and products catering to their particular needs [64]. Consumers also get automatic and tailored comparisons of prices and features, reducing the price in terms of time consuming and effort [65]. Thus, it is necessary to utilise cost as the strategy for helping in buyers' decision. Then, convenience can be defined as everything that can be done and necessary to smooth the process of exchange [66]. These attributes are online acting as distribution channel, downloadable products and services, real time accessibility, disintermediation and new intermediaries, and direct selling [63]. This main Internet channel as convenience is not the possibility of selling products online, rather its capability to build relations with customers [64]. Last, communication is defined as communicating with the consumer about the sustainability solutions the firm provides through its products and services, and communicate with consumer and other stakeholders [67]. The attributes are mass customization, personalization goods, mediums for conveying information, content publishing, online advertising, and online sales promotion [63]. This online communication is not only to advertise products, but also to build a purchase relation and create a perception of trust in buying. Previous research indicated that Customer, Cost, Convenience, and Communication are positive factors while s-commerce users are buying products and services [68][69] Furthermore, this study presents further hypotheses as follows:

H6: Customer value will have a positive effect on buying decisions for second-hand products

H7: Cost to the customer will have a positive effect on buying decisions for second-hand products

H8: Convenience will have a positive effect on buying decisions for second-hand products

H9: Communication will have a positive effect on buying decisions for second-hand products

\section{Conclusion}

This study has proposed a conceptual framework of s-commerce buying decision for second-hand products. It is based on the trust model for consumer Internet shopping and constructs of digital marketing mix to investigate behavioral of buying decision for s-commerce users. The further empirical study will be carried out by the questionnaires and will be analysed by using structural equation modelling techniques. This model will provide a useful tool to understand and predict factors affecting the s-commerce buying decision for second-hand products. 


\section{References}

[1] T.P. Liang,C.P. Wai. Introduction to the special issue: mobile commerce applications International Journal of Electronic Commerce. 2004, 8 (3): 7-17.

[2] The Electronic Transactions Development Agency. Value of e-Commerce Survey in Thailand. 2017, Available: https://www.etda.or.th/content/value-of-e-commerce-survey-in-thailand-2017.html

[3] J. Beerse. Social networks influence $74 \%$ of consumers buying decisions. 2011, Available: https://sproutsocial.com/insights/

[4] Vision Critical. New data on how social media drives purchasing. 2013, Available: https://www.visioncritical.de/new-data-how-social-media-drives-purchasing/

[5] F. Zeng, L Huang, W. Dou. Social factors in user perceptions and responses to advertising in online social networking communities. Journal of Interactive Advertising. 2009, 10 (1): 1-3.

[6] L. Zhou, P. Zhang, HD. Zimmermann. Social commerce research: An integrated view. Electronic Commerce Research and Applications. 2013, 12 (2): 61-68.

[7] Y. Akrimi, Khemakhem R. What Drive Consumers to Spread the word in Social Media? Journal of Marketing Research and Case Studies. 2012, (14).

[8] Z. Huang and M. Benyoucef. From e-commerce to social commerce: A close look at design features. Electronic Commerce Research and Applications. 2013, 12(4): 246-259.

[9] R.Olbrich and C. Holsing. Modeling consumer purchasing behavior in social shopping communities with clickstream data. International Journal of Electronic commerce. 2011, 16 (2).15-40.

[10] Gumtree commissioned Galaxy Research to prepare the Second Hand Economy Report. 2017, Available: https://www.gumtree.com.au/second-hand-economy/

[11] The Kijiji Second-Hand Economy Index REPORT. 2017, Available: https://www.kijiji.ca/kijijicentral/app/uploads/2016/08/2017-Index1.pdf

[12] H. Chu. A conceptual model of motivations for consumer resale on $\mathrm{C} 2 \mathrm{C}$ websites. The Service Industries Journal. 2013, 33 (15-16): 1527-1543.

[13] DL. Hoffman, TP. Novak. Flow online: lessons learned and future prospects. Journal of interactive marketing. 2009.

[14] AA. Alalwan, NP. Rana, YK. Dwivedi. Social media in marketing: A review and analysis of the existing literature. Telematics and informatics .2017, 34 .

[15] D. Guiot, D. Roux. A second-hand shoppers' motivation scale: Antecedents, consequences, and implications for retailers. Journal of Retailing. 2010.

[16] SC. Chu and Y. Kim. Determinants of consumer engagement in electronic word-of-mouth (eWOM) in social networking sites. International journal of Advertising. 2011, 30 (1): 47-75

[17] TP. Liang, YT. Ho, YW. Li, E. Turban. What drives social commerce: The role of social support and relationship quality. International Journal of Electronic Commerce. 2011, 16 (2): 69-90.

[18] Gefen, D. E-commerce: the role of familiarity and trust. International Journal of Management Science. 2000, 28 (6): 725-737.

[19] S. Kim and H. Park. Effect of various characteristics of social commerce (s-commerce) on consumers" trust and trust performance. International Journal of information Management. 2013, 33 (2): 318-322.

[20] J. Sihvonen , L.L.M. Turunen. As good as new - valuing fashion brands in the online second-hand markets. Journal of Product \& Brand Management. 2016, 25 (3): 285-295.

[21] J.V. Chen, S. Bo-chiuan,A.E. Widjaja. Facebook C2C social commerce: Astudy of online impulse buying. Decision support systems. 2016, 83: 57-69.

[22] A.T. Stephen and O. Toubia. Deriving value from social commerce networks. Journal of Marketing Research. 2010, 47 (20). 215-228.

[23] N. Hajili. Social commerce constructs and consumer's intention to buy. International Journal of Information Management. 2015, 35 (2): 183-191. 
[24] D. Roberts, R. Adams. Agenda development for marketing research: the user's voice. 2010, 52 (3): 329-352.

[25] D. Godes, JC. Silva. Sequential and temporal dynamics of online opinion. Marketing Science. 2012, 31 (3): 448 473.

[26] WW. Moe, DA. Schweidel. Online product opinions: Incidence, evaluation, and evolution. Marketing Science. 2012, 31 (3): 372-386.

[27] P. Kotler, G. Armstrong, J. Saunders, V. Wong. Principles of Marketing, Second European Edition. London. 1999.

[28] KL. Wang, Y. Wang, JT. Yao. A comparative study on marketing mix models for digital products. Internet and Network Economics Proceedings of First International Workshop. 2005, 660-669.

[29] Y. Wang. K.L. Wang, J.T. Yao. Marketing mixes for digital products: a study of the markets paces in China. International Journal of Technology Marketing. 2007, 4 (1): 15-42.

[30] P.K. Kannan, Hongshuang "Alice" Li. Digital marketing: A framework, review and research agenda. International Journal of Research in Marketing. 2017, 34 (1): 22-45.

[31] A Pomering. Marketing for sustainability: Extending the conceptualisation of the marketing mix to drive value for individuals and society at large. 2017, 25 (2): 157-165.

[32] F. Habibi, C.A. Hamilton, M.J. Valos, M. Callaghan . ). E-marketing orientation and social media implementation in B2B marketing. European Business Review.2015, 27(6): 638-655.

[33] K. Govindan,P. Mohapatra. Trust computations and trust dynamics in mobile adhoc networks: A survey. Communications Surveys \& Tutorials, IEEE. 2012. 14 (2): 279-298

[34] Fukuyama, F. Trust: The social virtues and the creation of prosperity. New York: The Free Press.1995.

[35] P. Keen,G. Ballance, S. Chan, S. Schrump. Electronic commerce relationships Trust by design. Englewood Cliffs, NJ: Prentice Hall. 1999.

[36] Y. H. Kim.Market analysis and issues of social commerce in Korea, KISDI. 2011, 23 (11): 41-63.

[37] YD. Wang, HH. Emurian . An overview of online trust: Concepts, elements, and implications. Computers in Human Behavior. 2015. 21 (1): 105-125

[38] G. Bansal, L. Chen. If they trust our e-commerce site, will they trust our social commerce site too? Differentiating the trust in e-commerce and s-commerce: The moderating role of privacy and security concerns. MWAIS 2011 Proceedings.2011.20.

[39] MKO. Lee, E. Turban. A trust model for consumer internet shopping. International Journal of electronic commerce.2001, 6 (1): 80 .

[40] S. Kim, H.Park. Effects of various characteristics of social commerce (s-commerce) on consumers' trust and trust performance. International Journal of Information Management. 2013, 33(2): 318-332.

[41] A.P. Fiske, Relativity within Moose culture: four incommensurable models of social relationships. Ethos 18. 1990: 80-204.

[42] N. Hajli, J. Sims, AH. Zadeh, MO. Richard. A social commerce investigation of the role of trust in a social networking site on purchase intentions. Journal of Business Research. 2007, 71: 133-141.

[43] SJ. Yoon. The antecedents and consequences of trust in online purchase decisions. Journal of Interactive Marketing. 2002, 16(2): 47-63.

[44] CMK. Cheung, MKO. Lee. Understanding consumer trust in Internet shopping: a multidisciplinary approach. Journal of the American Society for Information Science and Technology. 2006, 57(4): 479-492.

[45] JK Park, F Gunn, SL Han. Multidimensional trust building in e-retailing: Cross-cultural differences in trust formation and implications for perceived risk. Journal of Retailing and Consumer Services. 2012, 19(3): 304-312.

[46] HW. Kim, Y. Xu, S. Gupta .Which is more important in Internet shopping, perceived price or trust? Electronic Commerce Research and Applications. 2012, 11: 241-252

[47] A. Nerkar, PW. Roberts. Technological and product-market experience and the success of new product introductions in the pharmaceutical industry. Strat. Manage. J. 2004, 25 (8-9): 779-799. 
[48] MAAM Leenders, B Wierenga. The effect of the marketing-R\&D interface on new product performance: The critical role of resources and scope. Int. J. Res. Mark. 2008, 25 (1): 56-68.

[49] P. Bjork, H. Kauppinen-Raisanen. A netnographic examination of travelers' online discussions of risks. Tourism Management Perspectives. 2012, 2-3: 65-71.

[50] M.C. Lee. Factors influencing the adoption of internet banking: an integration of TAM and TPB with perceived risk and perceived benefit. Electron. Commerce. Res. Appl.2009, 8 (3): 130-141.

[51] M. Koufaris, W. Hampton-Sosa The development of initial trust in an online company be new customers. Information \& Management. 2004, 41(3): 377-397.

[52] S. Janda, PJ. Trocchia, KP. Gwinner. Consumer perceptions of Internet retail service quality. International Journal of Service Industry Management. 2002, 13(5): 412-431.

[53] M Koufaris, W Hampton-Sosa. The development of initial trust in an online company by new customers. Information \& Management. 2004, 41 (3): 377-397.

[54] J Yang, AG Hauptmann. (Un)Reliability of video concept detection in Proceedings of the ACM International Conference on Image and Video Retrieval. 2008: 85.

[55] D. Lee, R. Larose, N. Rifon. Keeping our network safe: A model of online protection behaviour. Behaviour \& Information Technology. 2008, 27 (5): 445-454.

[56] N. Mohamed, I.H. Ahmad. Information privacy concerns, antecedents and privacy measure use in social networking sites: Evidence from Malaysia. Computers in Human Behavior. 2012, 28: 2366-2375.

[57] R. LaRose, NJ. Rifon. Promoting i-safety: Effects of privacy warnings and privacy seals on risk assessment and online privacy behavior. Journal of Consumer. 2007. 41 (1): 127-149.

[58] FD. Davis. Perceived usefulness, perceived ease of use, and user acceptance of information technology. MIS Quarterly. 1989, 13 (3): 319-339.

[59] SL. Jarvenpaa, N. Tractinsky. Consumer trust in an Internet store: A cross-cultural validation. Journal of Computer-Mediated Communication. 1999, 5 (2): 1-35.

[60] SL. Jarvenpaa, K. Knoll, DE. Leidner. Is anybody out there? Antecedents of trust in global virtual teams. Journal of Management Information Systems. 1998, 14 (4): 29-64.

[61] Gefen, D., and Keil, M. The impact of developer responsiveness on perceptions of usefulness and ease of use: An extension of the technolog y acceptance model. DATABASE for Advances in Information Systems, 29, 2 (1998), $35-49$.

[62] KL Keller, DR Lehmann (2006). Brands and Branding: Research Findings and Future Priorities. Marketing Science. 2006, 25 (6): 740-759.

[63] C. Krueger, N. Lu, PMC. Swatman. Success factors for online music marketing-eTransformation: from the four P's to the four C's. The proceeding of CollECTeR Latin America, Santiago, Chile.2003.

[64] GD. Bhatt, AF. Emdad. An analysis of the virtual value chain in electronic commerce. Logistics Information Management.2001, 14 (2): 78-85.

[65] G. Dominici. Holonic Production System to Obtain Flexibility for Customer Satisfaction. Journal of Service Science and Management. 2018a, 1 (3): 251-254.

[66] J. Yudelson J. Adapting McCarthy's Four P's for the Twenty-First Century. Journal of Marketing Education. 1999, 21(1): 60-67.

[67] M. Hayward, FM. Belz, K. Peattie. Any colour you like as long as it's any colour you like. International Commerce Review. 2009, 2-4: 94-95.

[68] SM. Burgess, JBEM. Steenkamp. Marketing renaissance: how research in emerging markets advances marketing science and practice. Int J Res Mark. 2006, 23(4): 337-356.

[69] A . Lemmens , C. Croux ,MG. Dekimpe. Consumer confidence in Europe: united in diversity? Int J Res Mark. 2007,24(2): 113-127. 